\author{
Санін М. О., викладач
}

Луганський НАУ

\title{
ПРИЛАД ДЛЯ ВИМІРЮВАННЯ ВНУТРІШНЬООЧНОГО ТИСКУ В РІЗНИХ ВИДІВ ТВАРИН
}

\section{Рецензент - кандидат ветеринарних наук П. І. Локес}

\begin{abstract}
Описаний компактний ицифровий прилад для вимірювання внутрішньоочного тиску (ВОT) у домашніх та сільськогосподарських тварин. Проведені виміри на еталонному водному стовпі на здорових кролях та конях. Були розроблені техніка встановлення приладу і вимірювання та вдосконалене програмне забезпечення приладу для підвищення точності його показників. Був виготовлений упор для виміру ВОТ у великих тварин. Метод є неінвазивним і не викликає занепокоєння тварин.
\end{abstract}

Ключові слова: кролі, коні, внутрішньоочний тиск, прилад для вимірювання ВОТ.

Постановка проблеми. Прилади для вимірювання внутрішньоочного тиску в гуманній медицині мають чимало модифікацій. Принципом неінвазивних методів вимірювання внутрішньоочного тиску (ВОТ) є деформація рогівки та відстежування іï викривлення в залежності від сили, що його викликає. Багато таких пристроїв досить коштовні, а інші потребують строго вертикальних або горизонтальних положень пацієнта при нерухомості ока та повік. Це спричиняє незручності або навіть неможливість використовувати їх на тваринах.

Аналіз основних досліджень і публікацій, у яких започатковано розв'язання проблеми. Нашими дослідженнями доведено [2, 3], що більшість порушень ока, пов'язаних із травматичним, токсичним або ендогенним чинниками, спричиняє реакцію його судинної оболонки. Ця реакція при дії низки чинників може призвести до виникнення запального процесу. За даними деяких авторів $[4,5,6]$, при цьому в 10-40 \% випадків підвищується ВОТ, що призводить до створення хибного кола порушень органа зору. Ці порушення діагностуються візуально, але інколи залишаються непоміченими до часу часткової або повної втрати зору у тварини.

Для ранньої діагностики підвищення ВОТ у людей застосовуються окремі прилади. Першими 3 них були прилади визначення тиску інтраокулярним методом. Сам принцип був небезпечний, оскільки порушував цілісність оболонки ока. Пізніше стали використовувати екстраокулярні принципи виміру внутрішньоочного тиску. Так, тонометри Маклакова і Гольдмана не порушували цілісності оболонок ока, проте мали прямий контакт із рогівкою. Тонометр Маклакова, як найпростіший спосіб виміру ВГД, використовується і до цього часу в медичних установах, а модифікації тонометра Гольдмана широко використовуються для виміру «істинного» ВОТ. Досить поширеним вважається спосіб безконтактного виміру за допомогою струменя теплого повітря, хоча такі тонометри $є$ досить коштовними. В якості прототипу нашої корисної моделі слід вважати тонометр ІГД-01 як найкомпактніший i доступний очний тонометр [4]. Проте у нього $\epsilon$ істотний недолік - строго вертикальне положення, що потребує нерухомості пацієнта і його очей, чого досить складно досягти на крупних тваринах при обстеженні їх великої кількості.

Нами розроблений тонометр, який визначає величину ВГД через віко в будь-якому положенні пацієнта. Прилад досить компактний.

Матеріал та методи дослідження. Основним методом вимірювання ВОТ слугував власне виготовлений прилад. Він має вигляд прямокутного блоку $8 \times 6$ см висотою $2,5 \mathrm{~cm}$ із 8-сегментним рідкокристалічним індикатором (PI). Робочий вимірювальний вузол, а також аналого-цифрова частина була виготовлена самостійно і не має аналогів. Програма інтерпретації результатів датчика і виводу на PI написана самостійно. Живиться прилад від акумулятора мобільного телефону. Можливі модифікації з трьома акумуляторами АAА або АА по 1,2 вольта кожен, або від 3 -х батарей того ж типорозміру, напругою 1,5 вольта кожна. Отриманий патент на корисну модель (UA№53961) (рис. 1).

Перші випробування приладу проводилися на водному стовпі з поліхлорвінілової трубки з еластичною мембраною на одному кінці. Величини тиску на мембрану регулювалися подачею повітря $з$ компресора. Проводився цей експеримент при постійній температурі, рівній $+12{ }^{\circ} \mathrm{C}$; внутрішній діаметр трубки - 38 мм. 


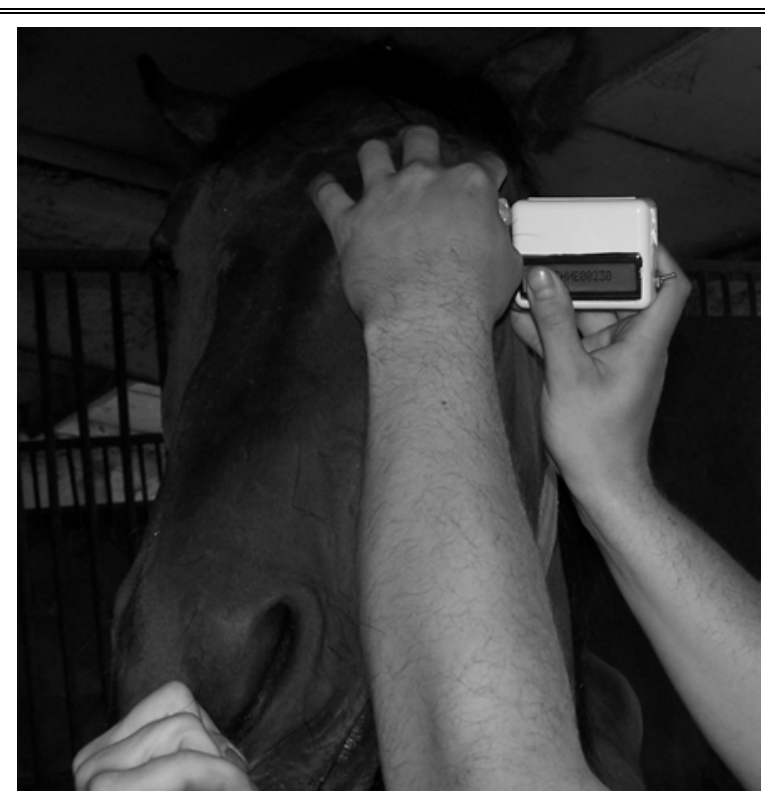

Рис 1. Вимірювання ВОТ у коня

Другий експеримент проводився на піддослідних тваринах - кролях у віці від 0,5 до 1,5 року та конях - у віці від 4 до 7 років. Очний тиск вимірювався за допомогою нашого приладу через повіко, в ділянці рогівки, без медикаментозного втручання за природного положення тіла тварин.

Результати дослідження. Мікрокомп'ютер приладу отримує дані зі спеціального датчика, значення якого залежать від градієнта внутрішньоочного тиску. У перших версіях приладу вони виводилися на рідкокристалічний екран без змін, у вигляді умовних одиниць. В останній версії приладу ВОТ вимірюється у міліметрах ртутного стовпа.

Для калібрування приладу, у відповідності 3 міжнародною системою одиниць, був використаний самостійно виготовлений водний стовп. До нього була приєднана камера, в яку закачувалося повітря, величина тиску регулювалася компресором. Була виведена формула градієнта тиску приладу і тиску усередині камери стовпа, що дозволило відображати величину в міліметрах ртутного стовпа.

Наступним етапом досліджень було вимірювання ВОТ у здорових кролів. Показники досить варіювали, але знаходилися в межах критерію достовірності Стьюдента 95 \% (табл. 1, вимірювання 1).
Удосконалення конструкції приладу, а саме його упору (частина приладу, що безпосередньо прилягає до віка), дало змогу зменшити розкид показників. Достовірність отримуваних даних підвищилася за критерієм Стьюдента до 99,9 \% (табл. 1, вимірювання 2).

\section{1. Величина ВОТ у кролів, $M \pm m$, п вимірювань $=4$}

\begin{tabular}{|c|c|c|}
\hline 哭 & $\begin{array}{c}\text { Величина ВОТ, } \\
\text { вимірювання } 1, \\
\text { мм рт. ст. }\end{array}$ & $\begin{array}{c}\text { Величина ВОТ, } \\
\text { вимірювання } 2 \text {, } \\
\text { мм рт. ст. }\end{array}$ \\
\hline 1 & $19,75 \pm 0,995 * *$ & $20,23 \pm 0,399 * * *$ \\
\hline 2 & $15,03 \pm 1,056^{*}$ & $18,35 \pm 0,397 * * *$ \\
\hline 3 & $19,43 \pm 1,066^{* *}$ & $23,40 \pm 0,500 * * *$ \\
\hline 4 & $20,53 \pm 0,800 * * *$ & $19,40 \pm 0,297 * * *$ \\
\hline 5 & $14,38 \pm 1,504 *$ & $15,20 \pm 0,363 * * *$ \\
\hline
\end{tabular}

Завдяки вимірам на очах кролів і статистичній обробці отриманих даних (за зменшенням середньоквадратичних відхилень у вибірці), з'ясовано положення приладу, при якому досягаються найбільш точні результати (рис. 2).

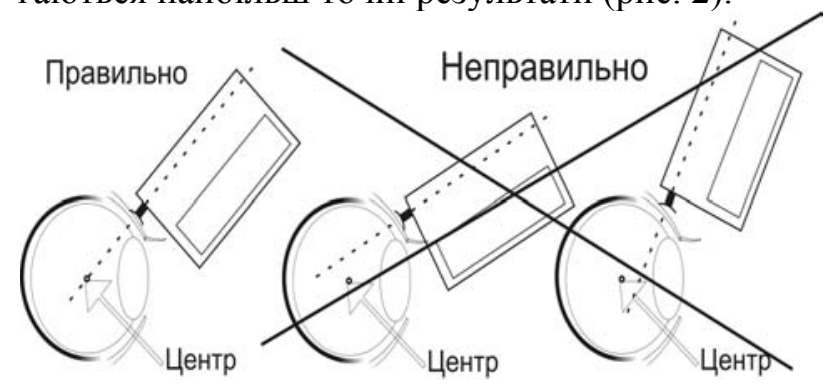

Рис. 2. Постановка приладу для вимірювання ВОТ на повіко, яка суміщає вісь приладу з центром очного яблука

Був виготовлений упор для виміру ВОТ у коней. Результати вимірювання наведені у таблиці 2 .

У більшості випадків для виміру ВОТ асистенту потрібно було окликнути тварину, надіти недоуздок і після короткого поглажування повіки тварини вона закривала досліджуване око. Притримуючи біля нижнього краю повіку рукою, можна було приступати до виміру. Вимірювання було безболісним і не викликало занепокоєння, про що свідчать значення частоти пульсу та дихання.

2. Вимірювання ВОТ у коней, $М \pm m$, п вимірювань $=3$

\begin{tabular}{|c|c|c|c|}
\hline Кличка & ВОТ, мм рт. ст. & Пульс, уд./хв & Дихання, дих./хв \\
\hline Еверест, 5 років (2005) & $20,09 \pm 0,240$ & $27,67 \pm 0,333$ & $17,33 \pm 0,333$ \\
\hline Чарлі-Браун, 7 років (2003) & $20,31 \pm 0,094$ & $31,33 \pm 0,667$ & $14,33 \pm 0,333$ \\
\hline Ранжер, 4 роки (2006) & $19,67 \pm 0,340$ & $35,67 \pm 0,333$ & $14,33 \pm 0,333$ \\
\hline
\end{tabular}

Примітка: всі значення достовірні $\mathrm{p}<0,001$ 


\section{Висновки:}

1. Прилад для вимірювання ВОТ у кролів та коней - компактний, надійний і простий у використанні, однак вимагає спеціальних навичок роботи.

2. Постановка приладу на орган зору тварини здійснюється через повіко, в ділянці рогівки, так, щоб поєднати вісь приладу і радіус вимірюваль-

\section{БІБЛІОГРАФІЯ}

1. Иванищев К. В. Способ измерения давления внутри органов через кожный покров и измерительный тонометр для его осуществления / Иванищев К. В., Огнев И. В., Пилецкий Г. К. [и др.] // RU2303943 (Россия). A61B 3/16 (2006.01).

2. Санін М. О. Рецидивуючий увеїт коней / Санін М. О. // Збірник наукових праць ЛНАУ. Ветеринарні науки. - №50/73. - Луганськ, 2005.

3. Санін M. O. Експериментальний увеїт у кролів / Санін М. О. // Збірка наук. праць ЛНАУ (ювілейний випуск). - №69(92). - Луганськ, 2006.

4. Herbert H. M. Risk factors for elevated intraocu- ної області, тобто направляючи вісь приладу на центр очного яблука.

3. Виготовлений упор для вимірювання ВОТ у коней дає можливість використовувати його для інших видів тварин.

4. Сама процедура виміру не викликає занепокоєння тварин.

lar pressure in uveitis / Herbert H. M., Viswanathan A., Jackson H., Lightman S. L. // J Glaucoma. 2004. - Vol. 13(2). - P. 96-99.

5. Sallam A. Outcome of raised intraocular pressure in uveitic eyes with and without a corticosteroidinduced hypertensive response/ Sallam A., Sheth H. G., Habot-Wilner Z, Lightman S. // American J Ophthlmol. - 2009. - Vol. 148 (2). - P. 207-213.

6. Sung $V$. C. Management of inflammatory glaucomas/ Sung V. C., Barton K. // Curr Opin Ophthalmol. - 2004. - Vol. 15 (2). - P. 136-140. 